\title{
Histomorphology of Colorectal Adenocarcinoma at Anatomic Pathology Unit of the H. Adam Malik Hospital Medan in 2019-2020
}

\author{
${ }^{1}$ Nova Sabrina Lubis, ${ }^{2}$ Lidya Imelda Laksmi, ${ }^{3} \mathrm{~T}$. Ibnu Alferraly, ${ }^{4}$ Betty, ${ }^{5}$ Soekimin \\ ${ }^{1}$ Department of Anatomical Pathology, Faculty of Medicine, \\ Universitas Sumatera Utara, Medan, Indonesia. \\ ²nova_shabrina@yahoo.com
}

\begin{abstract}
Background: Colorectal carcinoma is a malignant epithelial tumor originating from the large intestine (colon and rectum) which shows differentiation of glands and mucin, accompanied by invasion between the stroma of the mucous muscularis layer to the submucosa layer. World Health Organitation (WHO) recommends reporting several histopathological features in colorectal carcinoma related to the prognosis of the patient.
\end{abstract}

Methods: This study is a descriptive study with a cross sectional approach. There were 60 samples diagnosed histopathologically as adenocarcinoma colorectal from paraffin block at RSUP H. Adam Malik Medan in 2019-2020. Data regarding age, sex, tumor location, and clinical stage were obtained from medical records. Slaid reviews were performed, histopathologic subtypes, grade, Lymphatic invasion, Intra Mural Vascular Invasion (IMVI), Extra Mural Vascular Invasion (EMVI), Perineural Invasion (PNI), tumor budding, TILs, and depth of invasion (T) were determined.

Results: The mean age of the patients was 51.9 years with a minimum age of 22 years and a maximum of 83 years, the most common age group was 50-59 years, men were found more than women, and the location of the tumor was most found in the rectum. The most histopathologic subtypes were adenocarcinoma NOS, with common grade was low grade (73.3\%). Lymphatic invasion was found in 22 cases (36.7\%), most vascular invasion found was EMVI (35\%), PNI was found in 16 cases $(26.7 \%)$, most tumor budding were low budding, most frequent grade of TILs was moderate, and most clinical stage is stage II.

Keyword: histomorphology, adenocarcinoma, colorectal

\section{INTRODUCTION}

Colorectal carcinoma is a malignant epithelial tumor originating from the large intestine (colon and rectum) which shows gland and mucin differentiation, accompanied by invasion between the stroma of the mucous muscularis layer to the submucosa layer. ${ }^{1}$ This cancer is the third most common malignancy in the world, and the second most common cause of death in the world. ${ }^{2}$ The incidence of colorectal carcinoma in Indonesia is reported at 12.8 per 100.000 adult population, and accounts for $9.5 \%$ of all cancer mortality. ${ }^{3}$ Data from GLOBOCAN shows that there are $30.017(8.6 \%)$ new cases of colorectal carcinoma. in Indonesia at 2018. Based on gender, colorectal carcinoma in men ranks second most frequently after lung cancer with $19.113(11.9 \%)$ new cases in 2018, and the fourth most common malignancy after breast, cervical and ovarian carcinoma with 10,904 (5.8\%) new cases in women. ${ }^{2}$ Colon and rectal carcinomoften grouped together because they share many features. ${ }^{1,4}$ The risk of developing this malignancy tends to be higher in men than women for reasons not fully known. It is suspected related with exposure to risk factor such as smoking and hormones. ${ }^{1}$ In addition, the risk of developing this disease also increases with age. ${ }^{1,5}$

World Health Organitation (WHO) recommends reporting additional histological features that need to be assessed in the reporting of colorectal carcinoma patients, including lymphatic invasion, Intra Mural Vascular Invasion (IMVI), Extra Mural Vascular Invasion (EMVI), Perineural Invasion (PNI), tumor budding, as well as a description of the immune respons. ${ }^{1}$ These histopathological assessments should be reported routinely in every case of colorectal adenocarcinoma, because this is related to the prognosis that will affect the outcome of the patients. 


\section{MATERIALS AND METHODS}

In this study, 60 samples of adenocarcinoma colorectal who underwent surgery at $\mathrm{H}$. Adam Malik General Hospital Medan in 2019-2020 were diagnosed histopathologically with Hematoxylin Eosin (H\&E) staining. Data regarding age, sex, tumor location, and clinical stage were obtained from medical records. While histopathologic subtypes, grade, Lymphatic invasion, Intra Mural Vascular Invasion (IMVI), Extra Mural Vascular Invasion (EMVI), Perineural Invasion (PNI), tumor budding, TILs, and depth of invasion (T) were determined from slaid review.

\section{RESULTS}

From this study obtained the mean age of the patient was 51,9 years with a minimum age of 22 years and a maximum of 83 years with the most common age group was 50-59 years. Male was more common than female (56.7\% vs $43,3 \%$ ), and the most colorectal adenocarcinoma locations were found in the rectum for 19 cases $(31.7 \%)$, followed in the colon for 18 cases (30\%), then 15 cases in the left colon (25\%), and the least number was found in the right colon by 8 cases $(13.3 \%)$.

Table 1. Distribution of colorectal adenocarcinoma samples based on clinical data for age,sex, and tumor location.

\begin{tabular}{|c|c|c|}
\hline Clinical data & $\mathrm{n}$ & Percentage (\%) \\
\hline \multicolumn{3}{|l|}{ Age } \\
\hline$<30$ years & 2 & 3,3 \\
\hline $30-39$ years & 10 & 16,7 \\
\hline $40-49$ years & 12 & 20,0 \\
\hline $50-59$ years & 22 & 36,7 \\
\hline $60-69$ years & 10 & 16,7 \\
\hline $70-79$ years & 3 & 5 \\
\hline$\geq 80$ years & 1 & 1,7 \\
\hline \multicolumn{3}{|l|}{ Sex } \\
\hline Male & 34 & 56,7 \\
\hline Female & 26 & 43,3 \\
\hline \multicolumn{3}{|l|}{ Tumor location } \\
\hline Colon & 18 & 30 \\
\hline Rectum & 19 & 31,7 \\
\hline right kolon & 8 & 13,3 \\
\hline left colon & 15 & 25 \\
\hline
\end{tabular}

The microscopic examination results showed that the majority of samples were a nonspecific histopathological type of colorectal adenocarcinoma as many as 52 cases (86.7\%), and 8 other cases had a specific histopathological type of colorectal carcinoma consisting of 6 cases of mucinous adenocarcinoma and 2 cases of serrated adenocarcinoma.

Table 2. Distribution of samples of colorectal adenocarcinoma patients based onhistopathological subtypes.

\begin{tabular}{lcc}
\hline Histopathological subtypes & $\mathrm{n}$ & Percentage (\%) \\
\hline Adenocarcinoma NOS & 52 & 86,7 \\
Mucinous adenocarcinoma & 6 & 10 \\
Serrated adenocarcinoma & 2 & 3,3 \\
\hline Amount & 60 & 100 \\
\hline
\end{tabular}

Grading colorectal adenocarcinoma in this study was assessed based on the percentage of the glandular structure according to the World Health Organization (WHO) in 2019. There were 41 cases of low grade adenocarcinoma NOS, and 11 cases of high grade adenocarcinoma NOS. Meanwhile, high grade mucinous adenocarcinoma was found in 6 cases, and low grade and high grade serrated adenocarcinoma each in 1 case. 
Table 3. Distribution of colorectal adenocarcinoma samples based on histological grading.

\begin{tabular}{lcccc}
\hline Histopathological subtypes & \multicolumn{4}{c}{ Grading } \\
\cline { 2 - 5 } & \multicolumn{2}{c}{ Low grade } & \multicolumn{2}{c}{ High grade } \\
\cline { 2 - 5 } & $\mathrm{n}$ & $\%$ & $\mathrm{n}$ & $\%$ \\
\hline Adenocarcinoma NOS & 41 & 68,3 & 11 & 18,3 \\
Mucinous adenocarcinoma & - & - & 6 & 10 \\
Serrated adenocarcinoma & 1 & 1,7 & 1 & 1,7 \\
\hline Amount & 42 & 70 & 18 & 30 \\
\hline
\end{tabular}

Colorectal adenocarcinoma with positive lymphatic invasion was found in 21 cases (35\%),IMVI as many as 13 cases (21.7\%), EMVI as many as 26 cases $(43.3 \%)$ and positive perineural invasion (PNI) 16 cases $(26.7 \%)$.

Table 4. Distribution of lymphatic invasion, IMVI, EMVI and PNI in colorectal adenocarcinoma samples.

\begin{tabular}{|c|c|c|c|c|c|c|c|c|}
\hline \multirow{3}{*}{$\begin{array}{l}\text { Histopathological } \\
\text { subtypes }\end{array}$} & \multicolumn{8}{|c|}{ Invasion } \\
\hline & \multicolumn{2}{|c|}{ Lymph } & \multicolumn{2}{|c|}{ IMVI } & \multicolumn{2}{|c|}{ EMVI } & \multicolumn{2}{|c|}{ PNI } \\
\hline & $\mathrm{n}$ & $\%$ & $\mathrm{n}$ & $\%$ & $\mathrm{n}$ & $\%$ & $\mathrm{n}$ & $\%$ \\
\hline Adenocarcinoma & 17 & 28,4 & 12 & 20 & 22 & 36,6 & 13 & 21,7 \\
\hline NOS & & & & & & & & \\
\hline $\begin{array}{l}\text { Mucinous } \\
\text { adenocarcinoma }\end{array}$ & 2 & 3,3 & - & - & 3 & 5 & 2 & 3,3 \\
\hline $\begin{array}{l}\text { Serrated } \\
\text { adenocarcinoma }\end{array}$ & 2 & 3,3 & 1 & 1,7 & 1 & 1,7 & 1 & 1,7 \\
\hline Amount & 21 & 35 & 13 & 21,7 & 26 & 43,3 & 16 & 26,7 \\
\hline
\end{tabular}

Assessment of tumor budding in this study obtained the most were low budding in 35 cases $(58 \%)$, followed by intermediate budding in 14 cases $(23 \%)$, and the lowest was high budding in 11 cases (19\%). Meanwhile, the stromal distribution of TILs in this study was found to be moderate as many as 34 cases $(57 \%)$.

Table 5. Distribution of budding tumors and stromal TILs in colorectal adenocarcinoma samples.

\begin{tabular}{|c|c|c|c|c|c|c|c|c|c|c|c|c|}
\hline \multirow{3}{*}{$\begin{array}{l}\text { Histopathological } \\
\text { subtypes }\end{array}$} & \multicolumn{6}{|c|}{ Tumor budding } & \multicolumn{6}{|c|}{ Stromal TILs } \\
\hline & \multicolumn{2}{|c|}{ Low } & \multicolumn{2}{|c|}{$\begin{array}{c}\text { Inter } \\
\text { mediate }\end{array}$} & \multicolumn{2}{|c|}{ High } & \multicolumn{2}{|c|}{$\begin{array}{c}\text { Minima } \\
1\end{array}$} & \multicolumn{2}{|c|}{ Moderate } & \multicolumn{2}{|c|}{ High } \\
\hline & $\mathrm{n}$ & $\%$ & $\mathrm{n}$ & $\%$ & $\mathrm{n}$ & $\%$ & $\mathrm{n}$ & $\%$ & $\mathrm{n}$ & $\%$ & $\mathrm{n}$ & $\%$ \\
\hline Adenocarcinoma & & & & & & & & & & & & \\
\hline NOS & 31 & 51 & 13 & 21 & 8 & 13 & 3 & 5 & 29 & 48,3 & 20 & 33 \\
\hline Mucinous & 3 & 5 & 1 & 2 & 2 & 4 & - & - & 4 & 7 & 2 & 33 \\
\hline Serrated & J & & & & & & & & & & & \\
\hline adenocarcinoma & 1 & 2 & - & - & 1 & 2 & - & - & 1 & 1,7 & 1 & 1,7 \\
\hline Amount & 35 & 58 & 14 & 23 & 11 & 19 & 3 & 5 & 34 & 57 & 23 & 38 \\
\hline
\end{tabular}

The distribution of colorectal adenocarcinoma samples based on the depth of tumor invasion ( $\mathrm{T}$ ) was mostly $\mathrm{T} 3$ as many as 43 cases $(71.7 \%)$, followed by T2 in 11 cases (18.3\%), then T4 as many as 6 cases (10\%), and not found. sample with T1. Meanwhile, based on KGB involvement $(\mathrm{N})$, there were 49 cases $(81.7 \%)$ without KGB involvement, and as many as 11 cases $(18.3 \%)$ with KGB involvement. Of the 60 samples of colorectal adenocarcinoma in this study, 51 cases $(85 \%)$ were found without metastasis and as many as 9 cases $(15 \%)$ with metastases. Based on the criteria for the TNM system, the most tumor stages were stage II in 37 cases (61.7\%), followed by stage I with 10 cases $(16.7 \%)$, then stage IV in 9 cases $(15 \%)$, and the least found was stage III in 4 cases $(6.7 \%)$. 
Table 6. Distribution of colorectal adenocarcinoma samples by tumor TNM stage.

\begin{tabular}{|c|c|c|c|c|c|c|c|c|c|c|c|c|}
\hline \multirow[t]{2}{*}{$\begin{array}{l}\text { Histopathological } \\
\text { subtypes }\end{array}$} & \multicolumn{4}{|c|}{$\begin{array}{l}\text { Depth of tumor } \\
\text { invasion }(\mathrm{T})\end{array}$} & \multicolumn{2}{|c|}{$\begin{array}{l}\text { Lymph nodes } \\
\text { involvement }\end{array}$} & \multicolumn{2}{|c|}{$\begin{array}{c}\text { Meta } \\
\text { stasis } \\
(\mathrm{M})\end{array}$} & \multicolumn{4}{|c|}{ Stage } \\
\hline & $\begin{array}{l}\mathrm{T} \\
1\end{array}$ & $\begin{array}{l}\mathrm{T} \\
2\end{array}$ & $\begin{array}{l}\mathrm{T} \\
3\end{array}$ & $\begin{array}{l}\mathrm{T} \\
4\end{array}$ & $\begin{array}{c}\mathrm{N} \\
0\end{array}$ & $\begin{array}{c}\mathrm{N} \\
1-2\end{array}$ & M0 & $\begin{array}{c}\mathrm{M} \\
1\end{array}$ & I & II & III & IV \\
\hline $\begin{array}{l}\text { Adenocarcinoma } \\
\text { NOS }\end{array}$ & - & 9 & 38 & 5 & 43 & 9 & 44 & 8 & 11 & 31 & 3 & 7 \\
\hline $\begin{array}{l}\text { Mucinous } \\
\text { adenocarcinoma } \\
\text { Serrated } \\
\text { adenocarcinoma }\end{array}$ & - & 1 & 4 & 1 & 4 & 2 & 5 & 1 & 2 & 2 & 1 & 1 \\
\hline Amount & - & 11 & 43 & 6 & 49 & 11 & 51 & 9 & 14 & 34 & 4 & 8 \\
\hline
\end{tabular}
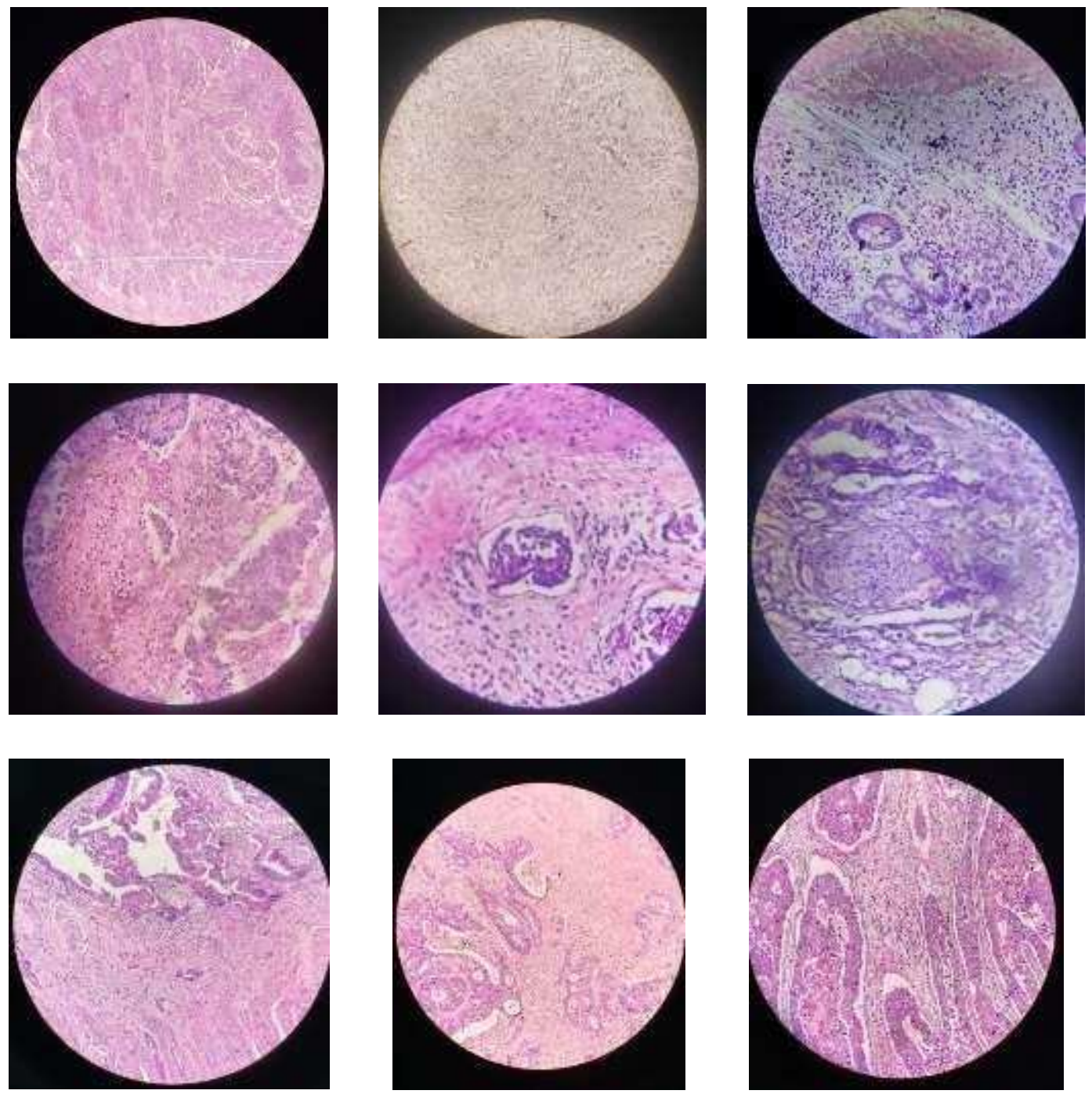

Figure 1. A. Low grade CRC (H\&E 100x), B. High grade CRC (H\&E 100x), C. Lymphatic invasion (H\&E 400x), D IMVI (H\&E 400x), E. EMVI (H\&E 400x), F. PNI (H\&E 400x), G. Moderately tumor budding (H\&E 200x), H. Moderate stromal TILs (H\&E 200x), I. High stromal TILs (H\&E 200x). 


\section{DISCUSSION}

The mean age of patients with colorectal carcinoma in this study was 51.9 years, with the most common age group being 50-59 years. Accordance with the theory stated in the WHO book 2019 and various literature which states that the most people with colorectal carcinoma are found in the age group over 50 years, because this cancer is closely related to dietary patterns and lifestyles that accumulate with age. This is also supported by various previous studies which found that the incidence of colorectal carcinoma is more dominated by the older age group, although several recent studies have also shown an increase incidence of patients young adults (under 40 years). ${ }^{6}$ People under 40 years old with colorectal adenocarcinoma generally have genetic disorders such as a history of HNPCC, FAP, chronic intestinal infection, and ulcerative colitis. The age plays more important role in rectal adenocarcinoma than the colon. ${ }^{7}$ In this study, 12 samples (20\%) were under 40 years old, with 2 of them even under 30 years (22 years and 28 years). However, the researchers did not get more information whether the young patients in this study were accompanied by other genetic disorders or not.

As many as $56.7 \%$ cases of colorectal carcinoma in this study were male. This is in accordance with the literature which explains that this malignancy affects men than women because of hormonal differences between men and women. ${ }^{1}$ Experimental research conducted by $\mathrm{Li}$ et al found that sex hormones in women, especially estrogen, have a protective role against colorectal carcinogenesis, indirectly by reducing secondary bile acids and insulin-like growth factor (IGF-1), or directly by regulating colonic epithelial cell growth or by inhibiting colorectal tumor proliferation via estrogen receptors, ${ }^{8} 26$ female patients in this study were more than 50 years old. This also indicates that most of these female patients have reached menopause, that decrease endogenous estrogen levels which leads to decreased antineoplastic estrogen activity against colorectal carcinoma. In addition, unhealthy lifestyle in men such as smoking and alcoholic beverages also trigger the vulnerability of men to suffer this malignancy. The most tumor location in this study was in the rectum as many as 19 cases (31.7\%), and the rarest location was in the right colon as many as 8 cases $(13.3 \%)$. Based on the literature, most cases of colorectal carcinoma appear in the left colon and rectum, ${ }^{1,9}$ in line with that Wang et al reported that the right colon is a rare location. ${ }^{10}$ Because in the right colon this cancer more likely cause hidden bleeding that causes atypical clinical symptoms, in contrast with tumor in the left colon or rectum that blockage and bloody the feses. One of the weaknesses of this study is still found medical records that do not include specific location of the tumor, because of that in this study researchers divided tumor location into four parts, namely the colon, rectum, right colon, and left colon.

Based on the WHO classification in 2019, colorectal adenocarcinoma consists of eleven histopathological subtypes that can be distinguished and have specific clinical and molecular characteristics. However, of all these subtypes this study only found three subtypes, were dominated by adenocarcinoma NOS (86.7\%), and there were two specific histopathological subtypes of colorectal carcinoma, namely mucinous adenocarcinoma and serrated adenocarcinoma. The grade in this study was assessed based on the percentage of gland differentiation components according to WHO 2019 which divides the grade of colorectal carcinoma into low grade and high grade. This study found that cases of low grade adenocarcinoma NOS were more common than high grade. This may be due to the increasing knowledge and information about this malignancy, as well as the increasing use of colonoscopy or other imaging support tools, which causes this malignancy to be detected more quickly. Although dominated by low grade adenocarcinoma NOS, this study also found 6 cases of high grade mucinous adenocarcinoma with a worse prognosis.

Lymphatic invasion positive was found in $35 \%$ of cases, slightly more than the study conducted by Betge et al that found lymphatic invasion positive in $30 \%$ of the study cases. ${ }^{11}$ Lymphatic invasion was associated with metastasis to lymph nodes, as well as in several other studies proved to be an independent prognostic indicator patients adenocarcinoma colorectal. ${ }^{1,12,13}$ Vascular invasion in this study is divided into Intramural Vascular Invasion (IMVI) and Extramural Vascular Invasion (EMVI). It was found that EMVI was more common than IMVI. This is in accordance with the literature and research conducted by Gibson et al which reported that the EMVI was more dominant than IMVI $(15.1 \%$ vs $3.3 \%){ }^{1,14}$ In line with that Betge et al also reported that EMVI more dominat than IMVI. ${ }^{11}$ The relationship of EMVI as an independent prognostic factor in the survival of colorectal carcinoma patients has been widely studied, while the role of IMVI is still not fully understood. This may be due anatomically and histologically EMVI is outside of the muscularis externa (serosa and subserosa) that it closer to the main 
branches of the blood vessels that supply the large intestine, whereas IMVI represents an end vascular with smaller diameter. Therefore, when there is invasion of the tumor into the blood vessels (vascular) it will be easier to see it in larger blood vessels.

Of the 60 samples studied, only 16 samples (36.7\%) were found to have positive perineural invasion (PNI). In accordance with the literature which states that the incidence of PNI in colorectal cancer ranges from $9 \%-30 \%{ }^{1,15,16}$ Zhoua et al reported that PNI status can be used as a complementary factor for TNM staging in colorectal carcinoma patients. His study found that there was a significant influence between PNI status on life expectancy in patients adenocarcinoma colorectal with stage II and III. Stage II patients are the most important group to benefit from PNI identification, because by determining their PNI status, they can be considered for adjuvant chemotherapy. In addition, Liebig et al also found that the reporting of PNI status was still low in routine daily reporting, even though in particular it was found that PNI was associated with histopathological indicators that showed a tumor aggressiveness and tumor metastatic behavior such as the presence of LVI, high tumor budding and the presence of metastasis to the KGB. ${ }^{16}$

Until now there is no standard method used to assess the infiltration of lymphocyte in adenocarcinoma colorectal. Therefore, in this study, the assessment of TILs was carried out based on the recommendations of the International Immuno-Onoclogy Biomarker Working Group in 2017 about how to assess TILs in solid tumors adopted from the method of assessing TILs in breast cancer according to the International TILs Working Group in $2014 .{ }^{17}$ Initially, there were hypothesis that lymphocyte cells that interact directly with carcinoma cells (intratumoral TILs) are more relevant than stromal TILs, but currently several studies have found stromal TILs to be a superior parameter. ${ }^{18-19}$ This may be due to intratumoral TILs are generally present in smaller numbers, more heterogeneous, and difficult to observe in H\&E staining. ${ }^{20}$ In addition, limiting the evaluation of TILs to the stromal compartment means that the number of TILs assessed will not be affected by the density and growth pattern of tumor cells. Klintrup et al reported that the number of inflammatory cells correlated with a good prognosis in colorectal carcinoma, ${ }^{18}$ in line with that Canna et al reported that the absence of CD4 $+\mathrm{T}$ lymphocytes in a study using CD4 + immunohistochemical staining correlated with poor survival. ${ }^{19}$

In this study the assessment of tumor budding was carried out in the invasive front tumor area after selecting the hotspot with the highest number of buds. The examination of tumor budding found that the highest proportion was low budding in 30 cases $(60 \%)$, followed by intermediate budding in 13 cases $(21.7 \%)$, and high budding in 11 cases $(18.3 \%)$. This is consistent with van Wyk et al study that found low budding was higher than high budding. ${ }^{20}$ However there were differences in the both about reporting system where in this study the researcher used the three tier scoring system recommended by the International Tumor Budding Consensus Conference (ITBCC) 2016, whereas van Wyk et al used the two tier scoring system. The three tier scoring system is recommended by the ITBCC 2016 because it can stratification the risk of pT1 and stage II colorectal cancer. Whereas in pT1, the intermediate and high budding was associated with an increased risk metastasis to lymph nodes, whereas in colorectal cancer stage II high budding was associated with a reduction survival life and increased recurrence. ${ }^{21}$ The most clinical stage in this study was stage II (61.7\%). This is accordance with the research conducted by Gunasekaran in Bali in 2019 which found that the highest stage was stage II (53.7\%), as well as several other studies in various regions in Indonesia which found the same results. ${ }^{22-24}$ It may be caused by due to the increasing use of colonoscopy as a screening in patients carcinoma colorectal that can be found at a lower stage than before.

\section{CONCLUSION}

After conducting research on 60 samples of adenocarcinoma colorectal it found that the average age of patients was 51.9 years with a minimum age of 22 years and a maximum of 83 years, the most common age group was 50-59 years, men was found more than women, and the most tumor location was found in the rectum. The most histopathologic subtypes were adenocarcinoma NOS, with common grade was low grade (73.3\%). Lymphatic invasion was found in 22 cases (36.7\%), most vascular invasion found was EMVI (35\%), PNI was found in 16 cases (26.7\%), most tumor budding were low budding, most frequent grade of TILs was moderate, and most clinical stage is stage II. 


\section{THANK YOU}

We would like to thank of the Departement of anatomical pathology, Universitas Sumatera Utara and H.Adam Malik General Hospital, Medan, Indonesia for their help and cooperation.

\section{ETHICAL APPROVAL}

Health Research Ethical Committee. Universitas Sumatera Utara, Medan, Indonesia approved this study.

\section{AUTHORS DETAILS}

First Author- dr. Nova Sabrina Lubis, resident of Anatomical Pathology Departement, Faculty of Medicine, Universitas Sumatera Utara, Medan, Indonesia.

Second Author- Dr. dr. Lidya Imelda Laksmi, M.Ked (PA), Sp.PA, Lecture and staff anatomical Pathology Departement, Faculty of Medicine, Universitas Sumatera Utara, Medan, Indonesia.

Third Author- Dr. dr. T. Ibnu Alferraly, M.Ked (PA), Sp.PA D. Bioeth, Lecture and staff anatomical Pathology Departement, Faculty of Medicine, Universitas Sumatera Utara, Medan, Indonesia.

Fourth Author- Dr. dr. Betty M.Ked (PA), Sp.PA, Lecture and staff anatomical Pathology Departement, Faculty of Medicine, Universitas Sumatera Utara, Medan, Indonesia.

Fifth author- dr. H. Soekimin, Sp.PA (K), Lecture and staff anatomical Pathology Departement, Faculty of Medicine, Universitas Sumatera Utara, Medan, Indonesia.

Corresponding Author-dr. Nova Sabrina Lubis, resident of Anatomical Pathology Departement, Faculty of Medicine, Universitas Sumatera Utara, Jl. Universitas no.1 Gedung Abdul Hakim, Keruntung, Medan, Indonesia.

Emai ID: novasabrina67@gmail.com

\section{REFERENCES}

1. Nagtegaal ID, Arends MJ, Salto-Tellez M. Colorectal adenocarcinoma. In WHO Classification of Tumours: Digestive System Tumours. $5^{\text {th }}$. WHO Classification of Tumours Editorial Board (Ed), International Agency for Research on Cancer. Lyon; 2019. pp.177-87.

2. Bray F, Ferlay J, Soerjomataram I, Siegel RL, Torre LA, Jemal A. Global Cancer Statistics 2018. GLOBOCAN Estimates Incidence and Mortality Worldwide for 36 Cancers in 185 Countries. 2018; 396-419.

3. Komite Penanggulangan Kanker Nasional Departemen Kesehatan Republik Indonesia. Pedoman Nasional Pelayanan Kedokteran Tatalaksana Kanker Kolorektal. 2017; http://kanker.kemkes.go.id/guidelines/PNPKkolorektal.pdf.

4. Nasution N. Karakteristik Pasien Kanker Kolorektal di RSUP H. Adam Malik Medan 2015-2017. Universitas Sumatera Utara; Repositori Institusi USU. 2018; http://repositori.usu.ac.id/handle/123456789/11025.

5. Park SH, Song CW, Kim YB, Kim YS, Chun HR, Lee JH, et al. Clinicopathological Characteristics of Colon Cancer Diagnosed at Primary Health Care Institutions. Intest Res. 2014;12(2):131-8.

6. Lugito NP. Clinical characteristic of young Indonesian colorectal cancer patients: A preliminary study. Medicinus. 2016; 5(3): 1- 3 .

7. Goldblum JR. Large bowel. Goldblum JR, Lamps LW, McKenney JK, Myers JL Rosai and Ackerman's Surgical Pathology Eleventh Edition. Elsevier; 2018. pp.693-702.

8. Li CY, Song B, Wang YY, Meng H, Guo SB, Liu LN, et al. Age at menarche and risk of colorectal cancer: A meta-analysis. PloS ONE. 2013; 8(6): 65645.

9. Underwood JCE. General and systemic pathology Edisi ke-2. Sarjadi, penterjemah. Patologi Umum dan Sistemik Edisi ke-2. EGC; 2000.

10. Wang CB, Shahjehan F, Merchea A, Li Z, Bekaii-Saab TS, Grothey A, et al. Impact of Tumor Location and Variables Associated With Overall Survival in Patient in Colorectal 
Cancer : A Mayo Clinic Colon and Rectal Cancer Registry Study Front Oncol. 2019; 9:76. doi: 10.3389/fonc.2019.00076.

11. Betge J, Pollheimer MJ, Lindtner RA. Intramural and Extramural Vascular Invasion in Colorectal Cancer: Prognostic Significance and Quality of Pathology Reporting. Cancer. 2012; 118(3):628-38.

12. College of American Pathologist (CAP). Protocol for the Examination of Resection Specimens From Patients With Primary Carcinoma of the Colon and Rectum. 2020.

13. Kim BH, Kim JM, Kang GH, Chang HJ, Kang DW, Kim JH, et al. Standardized Pathology Report for Colorectal Cancer, $2^{\text {nd }}$ Edition. Journal of Pathology and Translational Medicine 2020; 54:1-19.

14. Gibson KM, Chan C, Chapuis PH, Dent OF, Bokey L. Mural and Extramural Venous Invasion and Prognosis in Colorectal Cancer. Diseases of the Colon \& Rectum Volume. 2014; 57: 8 .

15. Zhoua Y,Wang H, Gong H, Caoa M, Zhang G, Wanga Y. Clinical Significance of Perineural Invasion in Stages II and III Colorectal Cancer. Pathology Research and Practice. 2015.

16. Liebig C, Ayala G, Wilks J, Verstovsek G, Liu H, Agarwal N, et al. Perineural Invasion Is an Independent Predictor of Outcome in Colorectal Cancer. American Society of Clinical Oncology. J Clin Oncol. 2009; 27(31): 5131-7.

17. Hendry S, Salgado R, Gevaert T, Russell PA, John T, Thapa B, et al. Assessing Tumor Infiltrating Lymphocytes in Solid Tumors: A Practical Review for Pathologists and Proposal for a Standardized Method from the International Immuno-Oncology Biomarkers Working Group: Part 1: Assessing the Host Immune Response, TILs in Invasive Breast Carcinoma and Ductal Carcinoma In Situ, Metastatic Tumor Deposits and Areas for Further Research. Adv Anat Pathol. 2017; 24(5): 235-51.

18. Klintrup K, Makinen JM, Kauppila S, Vare PO, Melkko J, Tuominen H, et al. Inflammation and prognosis in colorectal cancer. Eur J Cancer. 2005; 41:2645-54. https://doi.org/10.1016/j.ejca.2005.07.017 PMID: 16239109.

19. Canna K, McArdle PA, McMillan DC, McNicol AM, Smith GW, McKee RF, et al. The relationship between tumour T-lymphocyte infiltration, the systemic inflammatory response and survival in patients undergoing curative resection for colorectal cancer. British Journal of Cancer. 2005; 92(4):651-4. https://doi.org/10.1038/sj.bjc.6602419 PMID: 15700032.

20. van Wyk HC, Roseweir A, Alexander P, Park JH, Horgan PG, McMillan DC, et al. The Relationship Between Tumor Budding, Tumor Microenvironment, and Survival in Patients with Primary Operable Colorectal Cancer. Ann Surg Oncol. 2019; 26:4397-404 https://doi.org/10.1245/s10434-019-07931-6.

21. Lugli A, Kirsch R, Ajioka YO, Bosman F, Cathomas G, Dawson H, et al. Recommendations for Reporting Tumor Budding in Colorectal Cancer Based on the International Tumor Budding Consensus Conference (ITBCC) 2016. Modern Pathology. 2017; 30:1299-1311.

22. Gunasekaran V, Ekawati NP, Sumadi WJ. Karakteristik klinikopatologi karsinoma kolorektal di RSUP Sanglah, Bali, Indonesia tahun 2013-2017. Intisari Sains Medis. 2019; 10(3): 552-6. doi: 10.15562/ism.v10i3.458.

23. Hilda S, Soekimin, Betty. Hubungan Tumor-Stroma Ratio (TSR) dengan Grading dan Staging Histologi pada Adenokarsinoma Kolorektal. http://repositori.usu.ac.id/handle/123456789/25474.

24. Pinarto R, Labeda I. Karakteristik Pasien Penderita Kanker Kolorektal di RSUP DR. Wahidin Sudirohusodo Makassar Periode Januari 2018 - Juni 2019. http://repository.unhas.ac.id/id/eprint/261. 